\title{
THE PROJECT AS AN EFFECTIVE TECHNOLOGY IN THE FORMATION OF SPEECH COMPETENCE AMONG FUTURE JUNIOR SPECIALISTS IN JOURNALISM
}

\section{Ponomarenko N. P.}

\section{INTRODUCTION}

In the dynamic XXI century, the competent approach is the strategic guidance of the international community, one of the leading directions in training of future specialists.

The idea that «to take a historical challenge of XXI century, the education is supposed to be focused on future, on solving the problems of the new century, on the development of key components of the fosterlings, on the formation of project culture in them, new methods of thinking and activity» prevails in educational community ${ }^{1}$.

The future journalist should build the paradigms of his own educational, professional, and cultural growth, manage the process of transforming social objects with new modern foundations. In a globalized society this particular person should be engaged in social relations, not under the pressure, but at his own discretion. His job should be the sphere of realization of his abilities, and education to a greater extend should act as a rational technology of development of professional and general culture ${ }^{2}$.

The speech competence of future junior specialists in journalism is one of the leading in professiograms. It is formed based on composition of speech and communicative skills, ability to think critically, creatively solve professional tasks in a dimension of professional functions. We think that project is one of the most effective methods.

Within this article, we will outline the theoretical and methodological essence of the project and will present the results of project application in the formation of speech competence among future junior specialists in journalism.

\footnotetext{
${ }^{1}$ Матяш Н.В. Генезис и сущность понятия «Проектная деятельность школьников». Совершенствование технологического образования учащейся молодёжи : сборник материалов Международной научно-практической конференции «Технологическое образование сельских школьников в современных условиях» (19-21 сентября 2000 года). Армавир : АГПИ, 2000. С. 146-154.

2 Чемерис I.M. Формування професійної компетентності майбутніх журналістів засобами іншомовних періодичних видань : автореф. дис. ... канд. пед. наук : 13.00.04. Київ, 2008. 20 с.
} 
The professional activity of a journalist involves continuous interaction in the sphere of subject-subject relationships. Hence, actual formed speech competence largely determines the character of this activity, makes professional growth and self-realization possible. Every day media workers solve problems connected with the necessity to make contacts with different people, to predict their behavior, to solve conflicts, to encourage actions or restain from inappropriate actions, to convince, to explain citizens the features of modern social processes. So the important task of professional education is searching for effective methods of formation of speech competence among future specialists in media.

The following methods were used during the research: general scientific methods (in the course of theoretical study of Ukrainian and foreign scientific base, related to the topic of research); the methods of observation and pedagogical experiment (to learn project application aspects as a technology of speech competence formation among future junior specialists in journalism); the method of the questionnaire and assessment of college students with major 061 Journalism (in order to study the level of speech competence formation in the context of project as well as traditional forms of education application).

\section{Theoretical and methodological principles of project technology}

The problem of communication in the process of studying was researched even by progressive pedagogues from the past. The origins of conscious efforts to synthesize the theoretical bases of the educational process are related to pedagogical activity and works of J. Komenskyj. The didactition in his work "The great didactics" for the first time theoretically proves and explains studying as a natural process which should ensure the development of education on a broad basis: "Alpha and omega of our didactics should be the research and discovery of the method, which allows teacher to teach less and students to learn more"3.

During many centuries the question of "technologization" of the educational process for increasing the effectiveness of speech training of future specialists remains relevant. "Education is a great industry branch and because of that should apply the methods of mass production. ...Its own "industrial revolution" is quite possible in education. Probably, only this way we can make the education effective" $"$. We agree with the researches and think that adaptability of the educational process acts as an indicator of its

3 Коменский Я.А. Великая дидактика. Избранные сочинения. Москва, 1965. 162 c. C. 162.

${ }^{4}$ Pressey S.L. A Third And Fourth Contribution Toward The Coming Revolution In Education. School and Society. 1932. Vol. 36. P. 668-672. 
quality because it answers the question in which way to perform training, speech training in particular.

Innovative technologies and methods of modern education became an object of research among both foreign and Ukrainian scientists. In scientific researches of A. Aleksuk, I. Dobroskok, V. Kotsura, S. Nikitchyna, V. Kremen, V. Iljin, S. Proleev, M. Lysenko, P. Sauh and others the general theoretical, scientific and practical problems of innovative paradigm in higher school, progressive forms and technologies of education, experience and perspectives of its application in educational practice were investigated ${ }^{5}$.

Application of the project within the conditions of educational system of higher educational institution (HEI) of I-II accreditation levels (now - an institution of professional pre-higher education) allows to solve a lot of problem tasks: to activate the independent activity of students, to form speech competence, to form creative competence as the part of speech competence, to develop the ability to use research methods, to activate perception and self-perseption, as well as self-fulfillment of the students.

The project is a subject of study both in foreign and Ukrainian pedagogy. The theoretical and conceptual principles of the project were researched by U. Babanskyi, B. Hershunskui, V. Huzieiev, H. Meandrov, Ye. Polat, H. Selevko, I. Trojanovskyi, I. Chechel, S. Shatskyi, E. Collings, J. Dewey, S. Haines, J. Ch. Jones, W.H. Kilpatrick, M. Knoll, D. Reinhard, Ch. R. Richards, J. D. Runkle, C. M. Woodward, and others.

Innovations in the educational process are related to active creation and implementation of new methods and ways for solving didactic tasks of training the specialist in a harmonious combination of classic traditional methods and results of creative pursuit, application of progressive technologies, original didactic ideas and forms of the educational process implementation ${ }^{6}$.

Application of the project allows to solve a lot of problem tasks: to form speech competence, to activate an independent activity of students, to develop the ability to use research methods, to activate perseption and self-perseption, as well as self-fulfillment of the students.

The term "project" and relevant activities were the subjects of researches of philosophers, psychologists, pedagogues (M. Kahan, V. Bezrukova, V. Huzieieva, V. Dokuchieva, I. Iermakov, V. Kukushyn, U. Mashbyts, Ye. Polat, A. Hutorskyi, H. Schedrovytskoho, and others).

It is considered, that for the first time project was applied in the sphere of education in 1920s in the USA due to problems method (later became known as "projects method"), developed by American philosopher and pedagogue

\footnotetext{
${ }^{5}$ Higher education the attack of the MOOCs. The Economist. 2013. July 20th.

${ }^{6}$ Ibid.
} 
J. Dewey. So, the projects method as the form of displaying project culture, the way of teaching students, developed in the depth of the gnosiological flow of pragmatism (from lat. pragmaticus - case, action).

The projects method was actively developing in 1920s. American psychologist and pedagogue W.H. Kilpatrick made a significant contribution in this process. The projects method became practical implementation of the pragmatism concept concerning studies and education, which was actively supported and developed by American philosophist, psychologist, and pedagogue J. Dewey. Special attention should be paid to the fact that methods, which are focused on scientific research as an example of creation the educational strategy within the humanistic direction and provide personal discoveries of both teachers and learners, are the basis of this concept. In 1918 professor W.H. Kilpatrick in his thorough work "The Projects Method" ("The Project Method: The Use Of The Purposeful Act In The Educative Process") laid theoretical principles of the projects method, and also offered the first classification of the projects according to their goals ${ }^{7}$.

Now there is a fundamental rethinking of the projects method and its application in the educational practice. This is evident from the fact that during the last decades scientists significantly increased their attention to application of project technologies in the educational processes of HEI. In practical terms, the idea that "education should go ahead, that is to be focused on future, on solving problems of the new century, on development of the key skills of students, on formation of their project culture, new ways of thinking and activity in them" is established ${ }^{8}$.

Project (from Greece words "techne" - art, craft, skill and "logos" - science) in pedagogical science is corsidered as "an instrument which creates unique prerequisetes for development of the key skills (social, policultural, informational, communicational, etc.) and independence of the students in archieving something new, stimulating his natural curiosity and creative potencial"'.

The projects method is the way to help bring person to the real life conditions at maximum and engage him in solving specific tasks within interpersonal and business communication and cooperation ${ }^{10}$.

${ }^{7}$ Kilpatrick W.H. The Project Method: The Use Of The Purposeful Act In The Educative Process. Teachers College Record. 1918. № 19. P. 319-334.

${ }_{8}$ Срмаков І.Г. Компетентнісний потенціал проектної діяльності. Проектна діяльність у школі / упоряд. : М. Голубенко. Київ : Шк. світ, 2007. С. 5-18. С. 13.

9 Срмаков І.Г. Матеріали до проекту. Компетентнісний потенціал проектної діяльності. URL: http://npu.edu.ua/ext/102/files/materyaly.doc (дата звернення: 28.04.2020).

${ }^{10}$ Матяш Н.В. Генезис и сущность понятия «Проектная деятельность школьников». Совершенствование технологического образования учащейся молодёжи : сборник материалов Международной научно-практической конференции «Технологическое образование сельских школьников в современных условиях» (19-21 сентября 2000 года). Армавир : АГПИ, 2000. С. 146-154. 
Functionally, project determines the interaction of purpose, content, approaches, methods, means of study, ways of control and correction, result, actions of teacher and student.

We consider the essence of project as the technology in functioning of the entire system of didactic methods (content, stages, methods, etc.), that adapts the educational process to the structional and organizational requirements of the educational design. Project as technology, in its turn, considers systhematic and consistent modeling of training solution of problematic situation, which require the process of searching efforts from the participants of the educational process, directed at investigation and development of the optimal ways of their solution (projects), their obligatory public defence and analysis of the implementation results.

Besides general determination of project essence as the technology, we offer a number of mandatory criteria requirements for its modern definition: availability of the educational problem, complexity and relevance of which responds to the educational requests and students' life problems; research principles of finding ways to solve the problem; activities structuring according to the classic design stages; modeling of the conditions for detection of the educational problem by the students (its definition, research; search for solutions; examination and testing of the versions; designing the final project (or its versions); its defence; correction and implementation); self-regulating character of the students creative activity; practical or theoretical (but in any case applied) meaning of the activity result (project) and application readiness (implementation); professional value of the activity (students gain knowledge, develop personal, communicative skills, master the necessary ways of thinking and action).

Modern understanding of the project as technology, in our opinion, is based on the fact that project education can be considered as a didactic system, and the projects method - as a component of the system, pedagogical technology, that provides not only knowledge integration, but also application of actual knowledge and gaining new one.

In the context of teaching future junior specialists in journalism and formation of their speech competence, we believe that the project - is the process of creative searching and investigating activity in order to achieve the desired result - obtaining of speech competence by future specialist.

It is worth noting, that projects method opens unlimited possibilities for implementation of communicative, interactive, group education technologies, it is the condition of the educational process effectiveness. Students are able to learn how to interact, to be organized and punctual, to learn how to clear and neatly express their thoughts and ask questions, to understand the essence of the problems of person, they are communicating 
with, creating the conditions for cooperation and encouraging to the group work where it is appropriate ${ }^{11}$.

We believe that implementation of the project method promotes the activation of students independent activity, development of skill to use research methods, activates perseption and self-perseption, students selfrealization, opens unlimited abilities for implementation of communicative, interactive, group technologies of education, makes the entire educational process highly efficient.

\section{The project as a technology of the speech competence formation of future junior specialists in journalism}

The meaning of competence approach for the training of the qualified graduate with major 061 Journalism (specialty "Publishing and editing") in conditions of higher educational institution of I-II levels of accreditation (now - the institution of professional pre-higher education), analysis of the research results of the Ukrainian and foreign scientists according to the differentiation of the key concepts of research, predictions of performance capabilities of professional functions in the sphere of journalism allows to determin components of the speech competence structure of future junior specialist in journalism. The structure of speech competence of junior specialist in journalism is an integral system which combines linguistic, sociolinguistic, pragmatic, and media-competence. Speech competence covers knowledge of grammar. Sociolinguistic competence includes linguistic and cultural studies, sociolinguistic and common cultural ompetence. Pragmatic competence combines terminological, text, lingvocultural, lexicographic, rhetorical competences ${ }^{12}$.

J. Dewey states, that for people who study, it is extremely important to stimulate their interest in knowledge they gain and may use in future life and activity $^{13}$. According to the opinion of J. Dewey, the process of teaching the specialty 061 Journalism for the students of professional prehigher education institution is effective upon condition that they are interested in gaining specific knowledge and skills within the formation of speech competence.

The task of the algorithmized technique of formation speech competence among future junior specialist in journalism consists in stimulation of the ability to think critically, apply analyzing skills, synthesis and evaluation of

${ }_{11}^{11}$ Higher education the attack of the MOOCs. The Economist. 2013. July 20th.

12 Пономаренко Н.П. Мовленнсва компетентність майбутніх молодших спеціалістів $з$ журналістики: зміст і структура. Інноваційна педагогіка. 2019. Випуск 15. С. 127-132.

${ }_{13}$ Knoll M. John Dewey und die Projektmethode. Zur Aufklдrung eines Missverstдndnisses. Bildung und Erziehung. 1992. Vol. 45. P. 89-108. URL: https://doi.org/10.7788/bue-1992-0108. 
new material, explain facts on the basic level, and also apply methods of information search, to express own thoughts clearly and precisely using narrative, description and analysis methods.

Research bases were the professional prehigher educational institutions, that train specialists in major 061 Journalism such as: Mykhailo Hrushevsky Humanitarian Pedagogical College of Bar, Machine Building College of Sumy State University, Ivan Franko Pryluky Humanitarian Pedagogical College. Formation of speech competence among future junior specialists during the experimental work was conducted in several stages: motivational (1 course), research (2-3 courses) and integrative (4 course). Projects method was very important on research and integrative stages.

The classic definition of project implementation stages was given by J.Ch. Jones. According to him, it passes the following stages: divergence (extension of the project boundaries to provide space broad enough for problem solving search); transformation (creating of the principles and concepts); convergence (choice of the best option among many alternatives $)^{14}$.

We believe, that participation of junior specialists in project allows to chose personal role in the system of collective relations between project participants (author of the idea, executor, participant, organizer) or reserves them the right to choose individual work (all roles are united by one person project executor), which promotes personal self-improvement of every future specialist in the process of speech competence formation.

We point out that project technologies allow creating a motivational situation for the formation and improvement of speech skills for solving problematic tasks; activating language and speech knowledge of the students within curriculum; form articulation and intonation speech skills during presentation of project research; stimulating individual creative activity during choosing and creating "project product".

In order to examine the supposition about positive influence of using the project as a technology of formation speech competence of the future junior specialists in journalism, part of the formational stage of pedagogical experiment was implemented.

We should point out, that during the main stage the lessons on "Editing of educational and reference literature" in experimental group (sixth semester of studying) were conducted using project method. In a control group, lessons on the same topics and corresponding number of teaching hours were conducted at the same time in traditional form.

${ }^{14}$ Jones J.Ch. Design Methods: seeds of human futures (2nd edition). London : John Wiley \& Sons Ltd., 1992. 407 p. 
The projects method within the experiment was used for the formation of speech competence of the future junior specialists in journalism as an integral, socially significant, personally qualitative characteristic, which combines system of values, interest in speech development and selfdevelopment, acquired functional language, speech, linguistic knowledge, professional speech skills, skills of verbal and non-verbal communication, experiences and abilities which provide dialog interaction with the subjects of publishing and journalistic processes.

Let's analyze the example of the project "Video dictionary "Familiar unknown Sumy", presented by the future junior specialists in journalism during the study of the discipline "Editing of educational and reference literature".

During the first stage, group learned the essence of the concept "video vocabulary". The participants of the project found out, that video vocabulary is one of the modern varieties of electronic vocabulary, which are video series, build on a certain principle of linguistic material, which is unchanged.

The project is relevant due to thefact that it is an absolutely new phenomenon in lexicography, but very dynamic and perspective; video vocabularies can be broadly used in different types and forms of educational activity.

It is baced on the fact that video vocabularies promote the formation of new knowledge among users, fully and laconically submit the material and visualize it. Visualization, laconicism and digitalization are the requirements of time.

Scientific researches on this topic were also studied. The participants of the group noticed that using the visualization method created a productive tool for linguistic and cultural studies, because the traditional methods of onyms analysis do not reproduce a complete overview and do not give the ability to use valuable material in general educational and scientific space the unique data and knowledge, most of which exists nowadays only in single paper variations (archival information, handwritten maps, population registers, etc. $)^{15}$.

For the project video vocabulary "Familiar unknown Sumy" the following characteristics were chosen: 1) it is virtual vocabulary; 2) lexicographical material - local history; 3) dictionary article - video blog

15 Надутенко М.В., Надутенко М.В. Віртуалізація ономастичної системи «Ономастика України». Слово $и$ словарь = Vocabulum etvocabularium: сборник научных статей / Нац. акад. наук Беларуси, Центр исслед. белорус. культуры, языка и лит., Ин-т языкознания имени Якуба Коласа ; редкол.: И.Л. Копылов (гл. ред.) и др. Минск : Беларуская навука, 2010. Вып. 16. С. 194-198.

16 Електронний словник «Відомі невідомі Суми» на YouTube-каналі. URL: https://youtu.be/14f_p8sZrEw (дата звернення: 28.04.2020). 
dedicated to certain lexical item of Sumy local charm; 4) vocabulary is created by alphabetic principle; 5) for the functional purpose it is similar to the definition dictionary, but different by the representation of the material, construction of dictionary article and stylistic interpretation of words.

Stages of work on the dictionary article are defined as follows: 1) Sumy residents survey, the purpose of which is to outline the concepts which cause assosiative series with "the city on Psel river"; 2) formation of the register of the homonyms linguistic dictionary (selection criterion - frequency of choice by recipients); 3) preparation of dictionary articles, which should promote the interest to the subject of description and push to the creation of this type of article independently; 4) selection of the bright, illustrative material; 5) consultation with the local history experts concerning the subject of interpretation; 6) footage shooting; 7) integration of video vocabulary into the virtual space (the YouTube-channel MashTV is used for this purpose), which gives the ability for the users to join the creation of quality video footage through questions, discussions, sharing.

The authors group determined that promising issues for the functioning of the "Familiar Unknown Sumy" video dictionary are the problem of construction, functioning and further implementation. To the advantages of video vocabularies the authors of the project included: effective and convenient search system; ability of users to add comments or join the dictionary construction; admins control over the use of video vocabulary; visualization of linguistic material.

It should be noted, that the project "Familiar Unknown Sumy" was presented by the authors (students of Machine Building College of Sumy State University) at the conference of young scientists "The first step into science" and became award winners ${ }^{17}$. At the same time, this project received the favorable comments from the head of the Ukrainian Lexicography Center - candidate of philological sciences M. Nadutenko ${ }^{18}$.

Pedagogical observation over students participation in educational projects made it possible to determine that with each stage of expanding the sphere of active professional communication of future journalists, the level of their professional training and speech competence increased. Future journalists were more confident in public speaking, they learned to manage emotional state during dispute, with the help of word as tool of future work, functional varieties of professional speech, they learned to adapt their speech to various occupational surprises, to avoid remarks and statements,

\footnotetext{
${ }^{17}$ Сайт конференції «Перший крок у науку». URL: http://studconf.sumdu.edu.ua/ (дата звернення: 28.04.2020).

${ }_{18}$ Сайт «Український лінгвістичний портал: мова, інформатика, лінгвістика». URL: https://www.ulif.org.ua/ (дата звернення: 28.04.2020).
} 
psychological barriers and inconveniences, to possess the ability to think productively at all times, to present unquestionable arguments, evidences, show respect, tact, courtesy, tolerance, to cause positive respons from conversation partner, necessary to resolve the case.

Summarizing information acquired during study of the formation of speech competence of future junior journalists in journalism, let's point out functions that are typical for the project:

- analytical (formulation of the a project task; selection and justification of the project theme; definition of the project goal; analysis of future activities necessary for the project implementation; problematization (the analytical process of work in the problem field) - separation of the tasks system (subproblems) that need to be solved during the execution of the project; mastering integrated knowledge for work in the problematic field, for solving the project task;

- research (carrying out the research inquiry while working in a problematic field of project; acquisition of abilities and research skills of project problem solving);

- predictive (predictive modeling of the project - determination of methods, means and resources that ensure the achievement of the project objective (solution of the project task), as well as compliance with the terms of its implementation);

- constructive (focus on the obtaining a practically significant result based on predictive knowledge - developing the content of the stages of the project task; selecting the procedure for collecting and processing necessary data; selecting the method of designing the results and scenario of the presentation; discussing the criteria for evaluating the project quality and method of its implementation);

- transformative (collecting, analyzing and generalizing of information from different sources; interim discussion of received data; control and correction of interim results according to the purpose; creation of a report on the results of project implementation);

- normative (passing all stages of the project implementation);

- educational (the formation of speech competence among the subjects of the educational process, upon condition that they acquire a system of knowledge and skills within the framework of the project task);

- personal (the formation of specific abilities among the future specialist, as well as the ability to learn; the manifestation of willpower, perseverance, independence by the project participants; self-improvement and self-development of students);

- sociopsychological (presence of creative interaction between the project participants (joint activities, communication); formation of group 
norms, values and relationships; leadership, responsibility; joint decisionmaking; communication skills; reflection).

Analysis of experimental work gives grounds to define the levels of intereaction between of subjects of the educational process:

- informational (exchange of scientific, educational and other information to form speech competence during the project task);

- practical (the joint activity of the subjects of the educational process during the implementation of the project task, aimed at the formation of speech competence);

- emotional (individual and joint impressions in the process and besed on the results of the implementation of the project task, which are accompanied by the experiences that occur during the formation of speech competence, as well as in the process of the project as a whole);

- ethical (adherence to the norms and rules of interaction agreed upon by all subjects of the educational process during the execution of the project task and the project as a whole, which ensures the formation of the speech competence of future junior specialists in journalismto the maximum).

S. Haines and B. Sinclair claim that it is quite difficult to effectively evaluate the project outcome as a matter of practice ${ }^{19}$. However, it should be remembered that project evaluation influences the self-esteem of the subjects of the educational process, and also allows them to choose topics for further discussion and study, to outline ways for their implementation.

During the pedagogical experiment, it was found out that participation of the future junior specialists in the project in the process of the formation of speech competence during study is ensured by: high level of project tasks complexity; application of the theoretical knowledge acquired by the future specialists, as well as practical skills; involvement of various information sources in the implementation of projects.

Therefore, in our opinion, it makes sense to consider the following as the criteria for evaluating the project of future junior journalists in the field of speech competence: the reasonableness of the proposed approaches and ways of solving the project task, as well as the conclusions obtained; fulfillment of the stipulated stages of designing and autonomy in the decision making that accompanies it, as well as the completion of such stages; the level of originality and creativity shown during the project task solving, as well as the presentation of the project itself; quality of project design; the completeness of the project presentation, as well as its reasoning and persuasiveness, which determine the quality of the report; erudition,

19 Haines S. Projects for the EFL classroom: Resource material for teachers. Edinburgh : Thomas Nelson and Sons, 1989. P. 23-90; Sinclair B. Learner autonomy: the Cross-cultural question. IATEFL Newsletter. 1997. Vol. 26. Iss. 139. P. 12-13. 
based on the amount of knowledge, skills and abilities acquired in the process of education and implementation of the project; completeness and reasoning of the answers to the formulated and emerging questions.

The analysis of the research work suggests that the implementation of the projects method during training of future junior journalists in the process of speech competence formation: is person oriented because in such conditions the goals and objectives set by each student are taken into account, as well as his needs, interests, motivations, abilities, individual characteristics, life experience; ensures preparation of future specialists for real practical activity by enhancing not only educational but also professional motivation; develops independent thinking in future junior journalism professionals; aims at establishing cause-effect relationships between phenomena through analysis; ensures the interaction of learners with each other as well as with teachers; contributes to the coordination of the actions of students, as well as increases their responsibility within the framework of the project task implementation and the implementation of the project as a whole.

In the course of the pedagogical experiment, it was found out that application of the project as formation technology of the speech competence of future junior journalists in journalism has several advantages, namely: absence of ready and simple decisions in the project implementation process; mastering not only knowledge but also practical skills to apply this knowledge to meet project objectives; development of self-education and self-control skills in future specialists; enhancing the information culture developing the skills of searching, collecting, processing, presenting the information; creation of conditions for comfortable learning due to ability to show their own skills in the process of speech competence formation; choice of the individual pace of the project task fulfilment as well as the fulfilment of project as a whole by the subjects of the educational process in accordance with their level of development, needs, interests and opportunities; increasing the motivation of students to acquire speech competence while training future junior journalism professionals; development of initiative and independence, creative abilities, ability of selfevaluation; opportunity to share the experience of solving the project problem with other subjects of the educational process; cross-curricular integration, which leads to the integration of knowledge and understanding of the need for cross-curricular communication in the process of speech competence formation; development of social qualities of future specialists.

During the experiment, five sessions were conducted using the project as a technology in the experimental group and as many lessons were conducted on the same topics in parallel in the traditional form in the control group. In both groups, after completing the sections, students completed the Compulsory Control Work (CCW) following the principles of academic integrity. 
All students of the experimental group successfully coped with the control work. There are no unsatisfactory CCW marks. The average mark on control work is 3.88 ; quality success was $66.67 \%$. All students in the control group also successfully coped with $\mathrm{CCW}$. There are no unsatisfactory marks. The average CCW mark was 3.67; qualitative success rate - 58,33\%. Qualitative achievement of students in the experimental group was 8.34 points higher than in the control group $(66.67 \%$ versus $58.33 \%)$.

To confirm whether the projects are effective technology for forming the speech competence of future junior journalism specialists, a survey was also conducted among students of the specialty 061 Journalism of educational institutions, which is part of the experiment.

The respondents mentioned the following advantages of the project: convenience and accessibility (72\%;) informality (12\%); interactivity and creativity (8\%), ability to show leadership skills (5\%); joint activity (3\%). When asked, "Do you consider it appropriate to use projects for speech competence?" 95\% said yes; 4\% said "not quite"; 1\% gave a negative answer.

Thus, both the traditional form of teaching and the use of the project as technology in the pedagogical process as a whole ensures the average level of success of students of the control and experimental groups. However, the indicator of qualitative success in the experimental group with a similar indicator in the control group allows us to conclude that the project methods of training in the educational process concerning traditional learning are more effective.

We compare the results of our study with the results of a similar study of the candidate of pedagogical sciences, teacher of Sumy State Pedagogical University named after A.S. Makarenko, Marina Yachmennyk ${ }^{20}$. The study was conducted in 2014-2019 among students of philological specialties of pedagogical universities to study the development of project skills in the formation of media literacy. The possibility of this comparison is due to the fact that the respondents of both studies receive a liberal arts education, having the same age characteristics. The research conducted by M. Yachmennyk generally confirmed our considerations regarding the effectiveness of the project application as a technology. We share the opinion of the researcher that the project as technology always offers a solution to any problem, which involves, on the one hand, the use of different methods, teaching aids, and on the other - the integration of knowledge, skills in different fields of science, technology, creativity. Thus,

\footnotetext{
20 Ячменик М.М. Підготовка майбутніх учителів української мови і літератури до використання засобів медіаосвіти у професійній діяльності : дис. ... канд. пед. наук : 13.00.04 / СумДПУ імені А.С. Макаренка. Суми, 2019. 358 с.
} 
the project as technology contributes to the acquisition of educational, professional and life experience, the experience of multidimensional communication models (co-partnership pedagogy) in the professional activities of future junior journalists.

Thus, the introduction of innovations in the educational process corresponds to social changes in society, to high European standards of training of competitive specialists.

\section{CONCLUSIONS}

Based on the analysis of scientific sources, the study of pedagogical experience and the results of a pedagogical experiment we come to the following conclusions: the application of the project method promotes the activation of students' independent activity, the development of the ability to use research methods, activates perception, self-perception and selfrealization of students, opens unlimited possibilities for group learning technology, makes the entire educational process highly effective. Given the creative approach of using the project as a technology, it will not only diversify learning but will also be a tool for the formation and development of the speech competency of future junior journalism professionals who would be ready to pursue a professional activity.

The methodological basis for the application of the project as technology should include a wide range of innovative forms, methods, tools, techniques of educational activity and cooperation with students since the project is a process of creative research to achieve the desired result - acquisition of speech competence by future junior specialists in journalism.

Our pedagogical observations with the participation of students in educational projects have made it possible to establish that with each stage of expanding the sphere of active professional communication of future journalists, the level of their professional training and speech competence increased. Future journalists were more confident in speaking, learned to take control over emotional state in a dispute, use words as means of future work, use functional varieties of professional speech, to adapt speech to various occupational surprises, to avoid replicas and expressions, psychological barriers and embarrassment, be able to think, give undeniable arguments, evidences, show respect, tact, courtesy, tolerance, elicit positive feedback from the conversation partner, necessary to solve the case.

\section{SUMMARY}

Within this article author outline the theoretical and methodological essence of the project and will present the results of project application in the formation of speech competence among future junior specialists in journalism. 
In order to examine the supposition about positive influence of using the project as a technology of formation speech competence of the future junior specialists in journalism, part of the formational stage of pedagogical experiment was implemented. During the main stage the lessons on "Editing of educational and reference literature" in experimental group (sixth semester of studying) were conducted using project method. In a control group, lessons on the same topics and corresponding number of teaching hours were conducted at the same time in traditional form.

Pedagogical observations with the participation of students in educational projects have made it possible to establish that with each stage of expanding the sphere of active professional communication of future journalists, the level of their professional training and speech competence increased. For example, future journalists were more confident in speaking, learned to take control over emotional state in a dispute, use words as means of future work, use functional varieties of professional speech, to adapt speech to various occupational surprises, to avoid replicas and expressions, psychological barriers and embarrassment, be able to think, give undeniable arguments, evidences, show respect, tact, courtesy, tolerance, elicit positive feedback from the conversation partner, necessary to solve the case.

\section{REFERENCES}

1. Електронний словник «Відомі невідомі Суми» на YouTubeканалі. URL: https://youtu.be/l4f_p8sZrEw (дата звернення: 28.04.2020).

2. Єрмаков І.Г. Компетентнісний потенціал проектної діяльності/ Проектна діяльність у школі / упоряд. : М. Голубенко. Київ : Шк. світ, 2007. C. $5-18$.

3. Єрмаков І.Г. Матеріали до проекту. Компетентнісний потенціал проектної діяльності. URL: http://npu.edu.ua/ext/102/files/materyaly.doc (дата звернення: 28.04.2020).

4. Коменский Я.А. Великая дидактика. Избранные сочинения. Москва, 1965. 162 с.

5. Матяш Н.В. Генезис и сущность понятия «Проектная деятельность школьников». Совершенствование технологического образования учащейся молодёжи : сборник материалов Международной научно-практической конференции «Технологическое образование сельских школьников в современных условиях» (19-21 сентября 2000 года). Армавир : АГПИ, 2000. С. 146-154.

6. Надутенко М.В., Надутенко М.В. Віртуалізація ономастичної системи «Ономастика України». Слово и словарь = Vocabulum etvocabularium : сборник научных статей / Нац. акад. наук Беларуси, Центр исслед. белорус. культуры, языка и лит., Ин-т языкознания 
имени Якуба Коласа ; редкол.: И.Л. Копылов (гл. ред.) и др. Минск : Беларуская навука, 2010. Вып. 16. С. 194-198.

7. Пономаренко Н.П. Мовленнєва компетентність майбутніх молодших спеціалістів 3 журналістики: зміст і структура. Інноваційна педагогіка. 2019. Випуск 15. С. 127-132.

8. Сайт конференції «Перший крок у науку». URL: http://studconf.sumdu.edu.ua/ (дата звернення: 28.04.2020).

9. Сайт «Український лінгвістичний портал: мова, інформатика, лінгвістика». URL: https://www.ulif.org.ua/ (дата звернення: 28.04.2020).

10. Чемерис I.M. Формування професійної компетентності майбутніх журналістів засобами іншомовних періодичних видань : автореф. дис. ... канд. пед. наук : 13.00.04. Київ, 2008. 20 с.

11. Ячменик М.М. Підготовка майбутніх учителів української мови і літератури до використання засобів медіаосвіти у професійній діяльності : дис. ... канд. пед. наук : 13.00.04 / СумДПУ імені А.С. Макаренка. Суми, 2019. 358 с.

12. Haines S. Projects for the EFL classroom: Resource material for teachers. Edinburgh : Thomas Nelson and Sons, 1989. P. 23-90.

13. Higher education the attack of the MOOCs. The Economist. 2013. July 20th.

14. Jones J. Ch. Design Methods: seeds of human futures (2nd edition). London : John Wiley \& Sons Ltd., 1992. 407 p.

15. Kilpatrick W.H. The Project Method: The Use Of The Purposeful Act In The Educative Process. Teachers College Record. 1918. № 19. P. 319-334.

16. Knoll M. John Dewey und die Projektmethode. Zur Aufklдrung eines Missverstzndnisses. Bildung und Erziehung. 1992. Vol. 45. P. 89-108. URL: https://doi.org/10.7788/bue-1992-0108.

17. Pressey S.L. A Third And Fourth Contribution Toward The Coming Revolution In Education. School and Society. 1932. Vol. 36. P. 668-672.

18. Sinclair B. Learner autonomy: the Cross-cultural question. IATEFL Newsletter. 1997. Vol. 26. Iss. 139. P. 12-13.

\section{Information about the author: Ponomarenko N. P.,}

Postgraduate Student at the Ukrainian Language and Literature Department

A. S. Makarenko Sumy State Pedagogical University, Teacher of Machine Building College Sumy State University 17, Taras Shevchenko Avenue, Sumy, Ukraine 